\title{
確率的商圏設定モデルの構造に関する研究
}

\section{藤 目 節 夫*}

Huff モデルに代表される従来の確率的商圈設定モデルは, Luce の提唱した個人選択公理をその理論的根 拠としている. しかしながら，Luce の個人選択公理を消費者の店舗選択行動に適用する場合，なぜ相対効 用度と選択確率の間に 1 対 1 の対応関係が存在するのか明らかでない.したがって, L.uce の個人選択公理 をその理論的根拠としている従来の確率的商圈設定モデルは, 消費者の店舗選択メカニズムが明確に定義さ れないままにモデルが構築されていると言える. 本研究は, 以上の観点から, 消費者の店舗選択メカニズム を明確に定義した新たな確率的商圏設定モデルを提案し，その有用性，従来のモデルとの関係を考察したも のである

\section{I 序論}

店舗の市場圏(小売商圈)ないし中心地の勢力圈設 定の問題は従来から地理学の重要な研究課題の一つ であった. この課題に対して，おそらく最初の，そ して重要な貢献をなしたのは Reilly (1931)であろう. 彼は「ある都市の小売業がその周辺のあるコミュニ ティから吸引する交易額は，その都市の人口に正比 例し，その都市とそのコミュニティとの距離の二乗 に反比例する」という関係をテキサス州において実 証的に発見し，これを小売引力の法則 (Law of Retail Gravitation) と名づけた (Reilly, 1931).この Reilly の成果はその後 Converse に受けつがれたが, 彼は 2 都市を結ぶ直線上で，2 都市それぞれの主た る勢力圈を画定する分岐点 (breaking point) を計算 する公式を導き出している (Converse, 1949). Reilly の小売引力の法則は, 本来勢力圏 (小売商圈)の画 定を意図したものでなく，この法則が勢力圈(小売 商圈)の画定と結びついて考えられるようになった のは, Converse がこの分岐点公式を導びいて以来 のことである. しかし, Reilly・Converse のモデル は，相当の規模をもつ，かなりの距離を隔てた 2 都 市間においてのみ適用が可能であり (Thompson, 1966), 都市規模が著しく異なる 2 都市間の場合に

\footnotetext{
* 愛媛大学・法文学部
}

見られる浮上現象を説明することができず，適用 が不充分であった.この問題点に着目したのが, Tuominen (1949) と Godlund (1956) であり, アポ ロニウスの円の原理を利用することにより，この問 題点を解決した.

これに対し，小売引力の法則を確率的視点から定 式化したのが Huff であった(Huff, 1964). Huff は Reilly の法則が経験的に抽出されたもので理論的根 拠が薄弱であること，決定論的であってデータの散 らばりを説明できないこと，個々の消費者の買物行 動を説明できないことなどを不満とし，個々の消費 者の買物行動を説明するモデルを開発した，中西 (1979)が指摘しているように，このハフ (Huff) モ デルは Reilly の小売引力の法則を延長したもので, 両モデルは同一の範疇に属するものであるが，一般 的に前者のモデルが唯一の境界を設定する目的で用 いられており，その意味で確定的商圈設定モデルで あるのに対し，後者は店舗の周辺に位置する消費者 が特定の店舗を利用する確率を求めるものであり， その意味で確率的商圈設定モデルといえるであろ 3. Huff 以後,一般にハフ (Huff) 型モデルと呼ば れる確率的商圈設定モデルや，同じ系譜に属する M. C. I. モデル (Nakanishi and Cooper, 1974) など が提案されたが，八フモデルも含めてこれらはいず れも心理学者 Luce の提唱した個人選択公理をその 
理論的根拋とした. Luce の個人選択公理とは, 個 々の消費者が買物トリップに出かける際の目的地の 選択が確率的であることを前提とし，「ある消費者 が目的地 $\mathrm{A}$ を選ぶ確率と $\mathrm{B}$ を選ふ確率の比は, この 消費者に対する Aの効用 (utility) と Bの効用の比に 等しい」と表現することができる(中西，1979).す なわち, 全効用に占めるある目的地の効用の比, 相 対効用度, がその目的地の選択確率に等しいとする ものである.

Luce の個人選択公理は相対効用度と選択確率の 間に 1 対 1 の対応関係を仮定しているが，この関係 の存在については何ら実証がなされていない，便宜 的に両者の間に 1 対 1 の対応関係を仮定しているだ けである. したがって, Luce の個人選択公理を自 明の理としてモデルが構築されている従来の確率的 商圈設定モデルは，店舗選択メカニズム，すなわち， 消費者が利用可能なすべての店舗を評価し，その評 価值を基準にして各店舗を相互に比較し，消費者に とり効用が最大となる店舗を利用するというメカニ ズム，が不明確であると指摘できる.

本研究は，このような問題点に着目し，上述の意 味での消費者の店舗選択メカニズムを明確に定義し， その上で新たな商圈設定の確率的モデルを提案する. そして松山市石井地区を研究地域にして得られた消 費者行動調査結果を用いて，新たに提案したモデル の有用性，ならびに本モデルと従来のモデルとの予 測結果を比較考察する.これが本研究の主要な目的 である. なお，本研究は八フモデルに代表される従 来の確率的商圏設定モデルの有用性を否定するもの ではなく，従来のモデルに欠けていた消費者の店舗 選択メカニズムに視点を置いて, 新たなモデルが構 築しうることを提案したものである.

\section{II 確率的商圈設定モデルの基本構造}

1）従来のモデルの基本構造 従来の確率的商圈設定モデルの基本構造は, Luce
の個人選択公理を用いて簡単に示すことができる. すなわち, 地区 $i$ に居住する消費者が店舗 $j$ から受 ける効用を $U_{i j}$ とすると, この消費者が選択可能な $n$ 個の店舗の中から, 特定の店舗 $j$ を選択する確率 $P_{i j}$ は, $n$ 個の店舗のもつ効用の総和 $\left(\sum_{j=1}^{n} U_{i j}\right)$ に占 める特定の店舗 $j$ のもつ効用 $\left(U_{i j}\right)$ の比, すなわち 相対効用度に等しいとするものである. この関係を 数式で示せば，次式のように表わされる.

$$
P_{i j}=\frac{U_{i j}}{\sum_{j=1}^{n} U_{i j}}
$$

序論で指摘したように，従来の確率的商圈設定モ デルにおいては，相対効用度と選択確率の間に 1 対 1 の線型の対応関係を仮定している.すなわち， $j$ なる店舗の占める相対効用度が，たとえば $20 \%$ の場 合，その店舗が選択される確率も $20 \%$ と仮定してい るのである. 前述したとおり，この仮定が成立しう る保証は何ら存在しないのであって, したがって, Luce の個人選択公理に基づいたモデルは，行動理 論的に見た場合，消費者の店舗選択行動が明確に表 現されていないのである.

従来の確率的商圈設定モデルには数多くのものが あるが，それらは効用 $U_{i j}$ をいかに規定するかによ って異なる. たとえば Huff は，効用 $U_{i j}$ が小売店 舗の規模 $S_{j}$ に正比例し, 地区 $i$ から店舗までの所 要時間 $T_{i j}$ のべき乗に反比例するとして, 次式で示 されるようなモデルを提案した (Huff 1964).

$$
P_{i j}=\frac{\frac{S_{j}}{T_{i j^{\lambda}}}}{\sum_{j=1}^{n} \frac{S_{j}}{T_{i j^{2}}}}
$$

ここで，入は時間の弾性值を示すパラメータであり， データから経験的に求められるものである.

Huff のモデルを修正したハフ型モデルには数多 くのものがあるが，代表的なものは店舗規模の弾性 值を示すパラメータ $\alpha$ を用いた次式で示されるもの であろう. 


$$
P_{i j}=\frac{\frac{S_{j}^{\alpha}}{T_{i j^{\alpha}}}}{\sum_{j=1}^{n} \frac{S_{j}^{\alpha}}{T_{i j^{\lambda}}}}
$$

ハフ, ないしハフ型モデルはこれまで数多くの実 証的研究例がある. その 1 例を示すと, 諸外国では Gambini, et al. (1967), Bucklin (1971); Huff and Lutz (1979) などの研究があり，我が国においては 山中の一連の研究 $(1971,1974,1979)$ や産業研究所 ${ }^{1)}$ (1979)などの研究がある.

これらハフ,ないしハフ型モデルをさらに拡張し たものに, Nakanishi and Cooperによる M. C. I. モ デル (Multiplicative Competitive Interaction Model) がある. このモデルは, 効用 $U_{i j}$ を構成する要因と して売場面積, 時間以外の要因をモデルに組み込む ことができるようになっており，基本的なモデル式 は次式で示される (Nakanishi and Cooper. 1974).

$$
P_{i j}=\frac{\prod_{k=1}^{q} X_{k i j}^{\beta k}}{\sum_{j=1}^{n}\left(\prod_{k=1}^{q} X_{k i j}^{\beta k}\right)}
$$

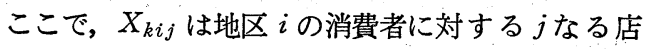
舗の $k$ 番目の要因, $\beta_{k}$ は $k$ 番目の要因にかかるパラ メータ，qは要因の数である. この M. C. I. モデル は，モデル式を見て明らかなようにハフモデル，八 フ型モデルを特殊な場合として含むより包括的なモ デルということができる.すなわち， $X_{k i j}$ として 売場面積と距離(時間)のみを用い，売場面積にかか るパラメータ $\beta_{k}$ の值を 1 とした場合がハフモデル, $\beta_{k}$ を 1 に固定しない場合が，八フ型モデルである2). この M.C.I. モデルについても近年いくつかの実証 的研究例が見られる. 外国では, Kotler (1971) が 店舗規模や交通時間のほかに，小売施設のイメージ， アクセシビリティー，価格レベルなどを説明要因と して，また Stanley and Sewall (1976) が店舗の規 模と自動車の運転距離に加えて, 消費者の店舗イメ 一ジを説明要因として，それぞれ実証的研究を行な っている. 我が国においては, 産業研究所(1979)が
店舗規模と距離以外に店舗の業態を識別するダミー 変数を導入したモデルを船橋市のデー夕に適用して 有意な結果を得ている.

以上が従来の確率的商圈設定モデルの基本構造と その実証的適用例である. この一連のモデルは前述 のごとく，消費者の店舗選択メカニズムが明確でな いという問題点を有しているが，同時に次のような いくつかの長所を有している.すなわち，i）消費者 の行動を確率的に把握していること，ii）未知パラメ 一夕の推定という問題はあるが，取り扱いが比較的 簡単なこと,などである.

ここで，未知パラメータの推定の問題が出たので， これについて若干触れておくと，まずハフモデルの パラメータについては，Huff 自身が用いた Fibonacci 探索法を用いて求めることができる. さらに, 八フ型, M.C.I. モデルについては, このモデルが対 数線型モデルであることから，回帰分析によってパ ラメータ推定を行なうことができる (Nakanishi and Cooper, 1974)33. なお, 八フモデル, ハフ型モデル については，パラメータの值を逐時変換して，コン ピューターにより予測值と実測值との適合度を最大 にするパラメータの值を探索する方法も可能であり， 実際この方法によりパラメータを推定した研究も見 られる(山中，1974)。

2）提案モデルの基本構造

1. モデルの基本的構造

ここでは, 従来の確率的商圈設定モデルの問題点 である消費者の店舗選択メカニズムを明確に定義し たモデルを提案することにする4) (簡単のため, 以後 このモデルを提案モデルと呼ぶ).

今，ある消費者がある特定の店舗に対して，それ が保有するあらゆる特性を考慮して, その店舗に対 する評価を決定すると仮定する，この評価值は，す べての消費者にとって同一ではなく, 個々の消費者 の社会・経済的属性により異なった值をとると考え られる. そこで, 同一地区に居住するすべての消費 
者を考えた場合, この評価値は平均値の回りに分布 していると考えられよう.この評価值の分布を：こ こでは正規分布に従うものと仮定することにする. ここで以下の議論を簡単にするため, 消費者にとっ て利用可能な店舗が三つある場合を仮定しょう。こ のように仮定しても議論の一般性は失なわれない.

そして，この三つの店鈛に対する評価值を，それぞ れ $x_{1}, x_{2}, x_{3}$ とすると, 前述の仮定より, この確率 変数は第 1 図で示されるような分布をするであろう.

このように仮定すると，ある地区に居住する人々 が 1 なる店舗を選択する確率 $P_{1}$ は, 評価值 $x_{1}$ が $x_{2}$ より大で, かつ $x_{1}$ が $x_{3}$ より大なる場合の確率で 表わされることになる. これを数式で示せば次のよ うになる.

$$
\begin{aligned}
P_{1}= & P_{r}\left[x_{1}>x_{2}, x_{1}>x_{3}\right] \\
= & \int_{-\infty}^{\infty} f_{1}\left(x_{1}\right) \int_{-\infty}^{x_{1}} f_{2}\left(x_{2}\right) \int_{-\infty}^{x_{1}} f_{3}\left(x_{3}\right) \\
& d x_{3} d x_{2} d x_{1} \\
= & \int_{-\infty}^{\infty} \frac{1}{\sqrt{2 \pi} \sigma_{1}} e^{-\left(x_{1}-\mu_{1}\right)^{2} / 2 \sigma_{1}{ }^{2}} \\
& \int_{-\infty}^{x_{1}} \frac{1}{\sqrt{2 \pi} \sigma_{2}} e^{-\left(x_{2}-\mu_{2}\right)^{2} / 2 \sigma_{2}{ }^{2}} \cdot \\
& \int_{-\infty}^{x_{1}} \frac{1}{\sqrt{2 \pi} \sigma_{3}} e^{-\left(x_{3}-\mu_{3}\right)^{2} / 2 \sigma_{3} 2} d x_{3} d x_{2} d x_{1}
\end{aligned}
$$

ここで, $x_{j}$ は仮定により $N\left[\mu_{j}, \sigma_{j}{ }^{2}\right]$ に従う正規確率 変数であり, $f_{j}\left(x_{j}\right)$ は $x_{j}$ の確率密度関数である. 今, $z_{j}=\left(x_{j}-\mu_{j}\right) / \sigma_{j}$ とすると, 式(5)は次のように 変形される.

$$
\begin{aligned}
P_{1}= & \int_{-\infty}^{\infty} \frac{1}{\sqrt{2 \pi}} e^{-z_{1}^{2} / 2} \int_{-\infty}^{K_{2}} \frac{1}{\sqrt{2 \pi}} e^{-z_{2}^{2 / 2}} \\
& \int_{-\infty}^{K_{3}} \frac{1}{\sqrt{2 \pi}} e^{-z_{3}^{2} / 2} d z_{3} d z_{2} d z_{1}
\end{aligned}
$$

ここで $K_{j}=\left(x_{1}-\mu_{j}\right) / \sigma_{j}$ である. さらに，

$$
\begin{aligned}
& F\left(K_{2}\right)=\int_{-\infty}^{K_{2}} \frac{1}{\sqrt{2 \pi}} e^{-z_{2}^{2} / 2} d z_{2} \\
& F\left(K_{3}\right)=\int_{-\infty}^{K_{3}} \frac{1}{\sqrt{2 \pi}} e^{-z_{3}^{2} / 2} d z_{3}
\end{aligned}
$$

とおくと，式(6)は次式のようになる.

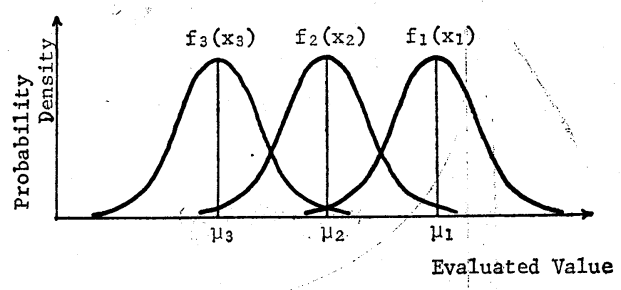

第 1 図“評価值の分布

$$
\begin{aligned}
P_{1} & =\int_{-\infty}^{\infty} \frac{1}{\sqrt{2 \pi}} e^{-z_{1} / 2} \cdot F\left(K_{2}\right) \cdot F\left(K_{3}\right) d z_{1} \\
& =\frac{1}{\sqrt{2 \pi}} \int_{-\infty}^{\infty} g\left(z_{1}\right) d z_{1}
\end{aligned}
$$

ここで

$$
g\left(z_{1}\right)=e^{-z_{1}^{2} / 2} \cdot F\left(K_{2}\right) \cdot F\left(K_{3}\right)
$$

である.

したがって, 最終的には式(7)は $z_{1}$ のみの関数形 であるから, 何らかの形で評価值 $x_{j}$ の分布形を特 定化できれば, 選択確率 $P_{1}$ は複合シンプソン (Simpson) 公式を用いて容易に数值積分で求めることが できる5)(山本, 1976). 第 2 , 第 3 の店舗に対する 選択確率 $P_{2}, P_{3}$ もまったく同様にして求めること が可能である. 詳細は省略するが, $P_{2}, P_{3}$ は次式で 示される.

$$
\begin{aligned}
P_{2}= & P_{r}\left[x_{2}>x_{1}, x_{2}>x_{3}\right] \\
= & \int_{-\infty}^{\infty} f_{2}\left(x_{2}\right) \int_{-\infty}^{x_{2}} f_{1}\left(x_{1}\right) \int_{-\infty}^{x_{2}} f_{3}\left(x_{3}\right) \\
& d x_{3} d x_{1} d x_{2} \\
P_{3}= & P_{r}\left[x_{3}>x_{1}, x_{3}>x_{2}\right] \\
= & \int_{-\infty}^{\infty} f_{3}\left(x_{3}\right) \int_{-\infty}^{x_{3}} f_{1}\left(x_{1}\right) \int_{-\infty}^{x_{3}} f_{2}\left(x_{2}\right) \\
& d x_{2} d x_{1} d x_{3}
\end{aligned}
$$

さて, 評価值 $x_{j}$ の平均值 $\mu_{j}$ は, 店舗と消費者間 の距離 $d_{i j}$ とは無関係ではない. なぜなら, 店舗か ら離れれば離れる程, 消費者は増大する距離抵抗を 克服する必要があり，そのため店舗に対する評価が 逓減するためである...この距離派減関数にはいくつ かのものが考えられるが，ここでは第 2 図に示した ように, $\mu_{j}$ が指数関数的に聥減する場合を仮定する. すなわち 


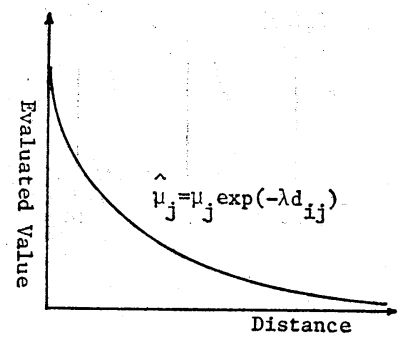

第 2 図評価值の距離聥減関数

$$
\hat{\beta}_{j}=\mu_{j} \exp \left(-\lambda d_{i j}\right)
$$

となり，したがって，選択確率 $P_{j}$ を求める式(5) (7)の $\mu_{j}$ はこの $\mu_{j}$ に置き換えられる必要がある.

以上が提案モデルの基本的構造であるが，モデル の基本式から明らかなように，本モデルにおいても， $0 \leq P_{i j} \leq 1, \sum_{j=1}^{n} P_{i j}=1$ という確率的モデルにおける 基本的条件は満たされている.

2）分布の特定化と未知パラメータの推定

前述の選択確率 $P_{j}$ は複合シンプソン公式による 数值積分を行なうと容易に求まるが，そのためには $x_{j}$ の分布を特定化する必要がある. $x_{j}$ の分布を特 定化するということは, $x_{j}$ が正規分布に従う確率変 数であることが仮定されているので， $x_{j}$ の平均值 $\mu_{j}$ と分散 $\sigma_{j}{ }^{2}$ を求める問題に帰着される. $\mu_{j}$ につ いては，これは小売店舗の魅力度の平均的な值を表 わすものであるから，たとえば八フモデルと同じよ うに店舗の売場面積とか，またはいくつかの評価構 成要因を合成したものが考えられよう．これに対し て分散 $\sigma_{j}{ }^{2}$ は， $\mu_{j}$ のように何らかの形であらかじめ 推定することはできない.したがって，今回は $\mu_{j}$ と $\sigma_{j}{ }^{2}$ の間に次式で示される仮定を置いて, 予測值 と実測值の適合度を最大にする $\sigma_{j}$ の值，すなわち $\beta$ の值を推定した ${ }^{6)}$.

$$
\sigma_{j}=\mu_{j}^{\beta}
$$

一方, 式(9)で示される距離聥減関数のパラメー タスの值もあらかじめ推定することができない，そ こで， $\beta$ の場合と同様，予測值と実測值の適合度を 最大にする $\lambda$ の值を推定した. すなわち， $\lambda$ と $\beta$ の
二つの未知パラメータに対し任意の值を与え，後述 する予測值と実測值の適合度を表わす RMS 誤差を 計算し，最小の $\mathrm{RMS}$ 誤差を与える ンピューターで探索するという方法を採用した。

\section{III 研究対象域と購買行動調查}

研究対象域は，愛媛県松山市石井地区を選択した (第 3 図)．この地区は，都心から南側の郊外部に位 置し, 地形が平坦で比較的自然的障害物が少なく, 近年急激な住宅立地を示している地区である.この 地区を研究対象域としたのは，筆者の日頃のフィー ルドであり，この地域に対する認識があること，地 形が平坦で自然的障害物が少ないので調査結果にこ れらに起因するゆがみが生じにくいと考えられたこ と, そしてダイエー南松山店, フジ古川店, セブン スター石井店という比較的大きな三つのスーパーが 立地しており，本研究で提案したモデルを検証する のに適していると考えたことなどによる.この対象 域には $500 \mathrm{~m} \times 500 \mathrm{~m}$ のメッシュをかぶせ，このメ ッシュを解析の基本単位域とした(第 3 図).

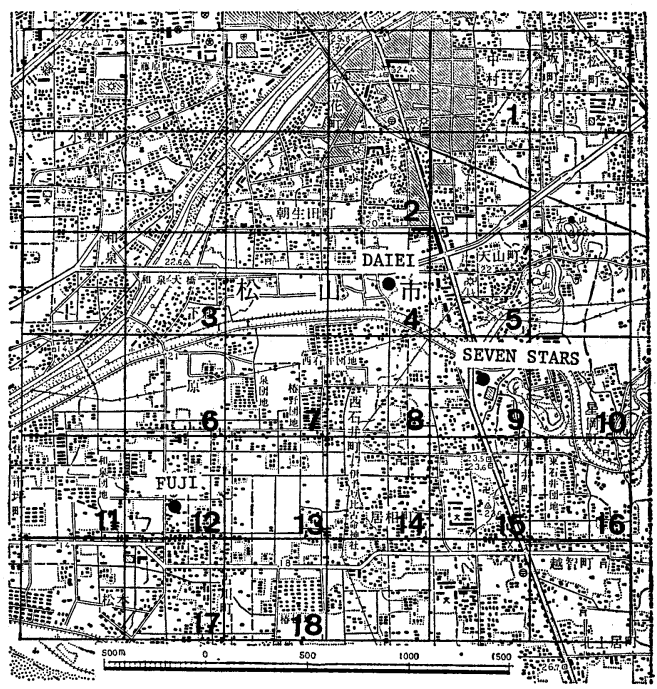

第 3 図、研究対象域と基本単位域 （数字は解析に使用したメッシュの番号を示す） 原図：国土地理院 25,000 分の 1 地形図. 
第 1 表 スーパーの諸特性

\begin{tabular}{|c|c|c|c|}
\hline & $\begin{array}{l}\text { ダイエー } \\
\text { 南松山店 }\end{array}$ & $\begin{array}{l}\text { ᄀ } \text { 吉 } \\
\text { 古店 }\end{array}$ & \begin{tabular}{|l} 
セブンスタ \\
一東石井店
\end{tabular} \\
\hline 売 場 床 面 積 & $4,000 \mathrm{~m}^{2}$ & 1,250 & 1,400 \\
\hline 従 業 員 数 & $110 人$ & 34 & 79 \\
\hline 駐車可能台数 & 415台 & 30 & 180 \\
\hline テナント 数 & 17店 & 4 & 2 \\
\hline レ ジ 台 数 & 30 & 10 & 13 \\
\hline
\end{tabular}

次に購買行動の調査であるが，これを実施する以 前に消費者の選択可能店舗を決定する必要がある. 今回は，新たに提案したモデルの有用性を検証する こと,この地区に上記 3 スーパー以外目立った小売 店舗が存在しないこと，などの理由により，この三 つのスーパーを選択可能店舗とし，これら 3 スーパ 一間の競合関係を予測することとした. 3 スーパー の主要な特性は第 1 表に示すとおりである. 購買行 動の調査は, 昭和54年11月23日と 25 日の両日，3 ス ーパーに調査員を配置し，同一時間内にこれらスー パーを訪れる消費者に対して, 出発地，購買品目， 三つのスーパーを知っているか否か，などをインタ ビュー調查した. そして生鮮食品を購入し，かつ 3 スーパーの存在を認知している消費者のみを以後の 解析の標本とした7)。この標本は，その出発地によ り前述のメッシュに配分されたが，メッシュによっ ては標本数が非常に少なくなり, 解析の結果にかな りのバイアスを生じると考えられたので，標本数が 20人以下のメッシュは解析から除外した. その結果, 全標本数 2,480 人のうち, 18 ッシュ, 798人を今回 の解析のための標本として用いることにした. 解析 に用いたメッシュは第 3 図に，また各メッシュの 3 スーパーに対する現実の選択確率は，第 2 表に示す とおりである.

\section{IV 解析結果とその考察}

1）従来のモデルによる予測結果

$S_{j}$ として店舗の売場面積, $T_{i j}$ として店舗と地区 間の直線距離を用いて消費者行動を予測した．第 3
第 2 表 各スーパーの利用者数とその構成比

\begin{tabular}{|c|c|c|c|c|c|c|}
\hline \multirow{2}{*}{$\begin{array}{l}\text { メッシ } \\
\text { =番号 }\end{array}$} & \multicolumn{2}{|c|}{ ダイエー } & \multicolumn{2}{|l|}{ フ } & \multicolumn{2}{|c|}{ セブンスター } \\
\hline & \begin{tabular}{l|} 
利用 \\
者数
\end{tabular} & 構成比 & $\begin{array}{l}\text { 利用 } \\
\text { 者数 }\end{array}$ & 構成比 & \begin{tabular}{l|} 
利用 \\
者数
\end{tabular} & 構成比 \\
\hline 1 & 16人 & $72.7 \%$ & 1人 & $4.6 \%$ & 5人 & $22.7 \%$ \\
\hline 2 & 20 & 80.0 & 2 & 8. 0 & 3 & 12.0 \\
\hline 3 & 7 & 31.8 & 14 & 63.6 & 1 & 4. 6 \\
\hline 4 & 30 & 78. 9 & 0 & 0.0 & 8 & 21.1 \\
\hline 5 & 19 & 50.0 & 0 & 0.0 & 19 & 50.0 \\
\hline 6 & 4 & 19.1 & 15 & 71.4 & 2 & 9.5 \\
\hline 7 & 8 & 19.5 & 25 & 61.0 & 8 & 19.5 \\
\hline 8 & 28 & 34.6 & 13 & 16. 1 & 40 & 49.3 \\
\hline 9 & 10 & 17. 0 & 0 & 0.0 & 49 & 83.0 \\
\hline 10 & 5 & 22.7 & 0 & 0.0 & 17 & 77.3 \\
\hline 11 & 5 & 5.8 & 80 & 91.9 & 2 & 2.3 \\
\hline 12 & 5 & 3.8 & 119 & 90.1 & 8 & 6.1 \\
\hline 13 & 2 & 8.0 & 20 & 80.0 & 3 & 12.0 \\
\hline 14 & 10 & 22.7 & 21 & 47.7 & 13 & 29.6 \\
\hline 15 & 9 & 39.1 & 1 & 4.4 & 13 & 56.5 \\
\hline 16 & 6 & 18.8 & 6 & 18.8 & 20 & 62.4 \\
\hline 17. & 2 & 5.4 & 35 & 94.6 & 0 & 0.0 \\
\hline 18 & 9 & 18. 4 & 37 & 75.5 & 3 & 6.1 \\
\hline
\end{tabular}

表と第 4 表に，それぞれハフモデルと八フ型モデル により予測された各メッシュの店舗選択確率を示 す。また，第 4 図と第 5 図は，各メッシュの 3 スー パーに対する現実の選択確率と，それに対応する各 モデルから予測された選択確率の関係を図示したも のである. 図中，横軸は各メッシュの 3 スーパーに 対する現実の選択確率を示し，縦軸はそれに対応 した予測選択確率を示す，適合度を表わす RMS 誤 差の值は，八フモデルが $15.86 \%$ ，八フ型モデルが 9.50\%であった. ここで RMS 誤差とは次式で示さ れる ${ }^{8}$.

$$
\text { RMS 誤差 }=\sqrt{\frac{\sum_{i=1}^{n} \sum_{j=1}^{m}\left(\hat{P}_{i j}-P_{i j}\right)^{2}}{n \times m}}
$$

ただし， $P_{i j}$ は $i$ なるメッシュにいる消費者がスー パー $j$ を現実に選択した確率， $\hat{P}_{i j}$ は $P_{i j}$ に対する 予測值， $n$ はメッシュの数， $m$ はスーパーの数であ る.

ハフモデルの場合, 最大の適合度の時の距離の弾 性值を示すパラメータ $\lambda$ の值は 2.90 であり, 一方,

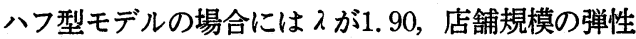


第 3 表 ハフモデルによる予測選択確率

\begin{tabular}{|c|c|c|c|}
\hline メッシュ番号 & ダイエー & ᄀ $シ シ$ & セブンスター \\
\hline$=1$ & $78.4 \%$ & $2.8 \%$ & $18.8 \%$ \\
\hline 2 & 96.9 & 0.6 & 2.5 \\
\hline 3 & 72.6 & 22.7 & 4. 7 \\
\hline 4 & 99.9 & 0.0 & 0.1 \\
\hline 5 & 73.7 & 0.5 & 25.8 \\
\hline 6 & 13.1 & 83.8 & 3.1 \\
\hline 7 & 54.7 & 35.5 & 9.8 \\
\hline 8 & 63.9 & 2.2 & 33.9 \\
\hline 9 & 0.2 & 0.0 & 99.8 \\
\hline 10 & 21.9 & 1.1 & 77.0 \\
\hline 11 & 4.1 & 94.5 & 1.4 \\
\hline 12 & 0.0 & 100.0 & 0.0 \\
\hline 13 & 17. 1 & 76.4 & 6.5 \\
\hline 14 & 58.7 & 20.7 & 20.6 \\
\hline 15 & 50.6 & 15.0 & 34.4 \\
\hline 16 & 26.3 & 5.0 & 68.7 \\
\hline 17 & 1.8 & 97.7 & 0.5 \\
\hline 18 & 8.4 & 85.1 & 6.5 \\
\hline
\end{tabular}

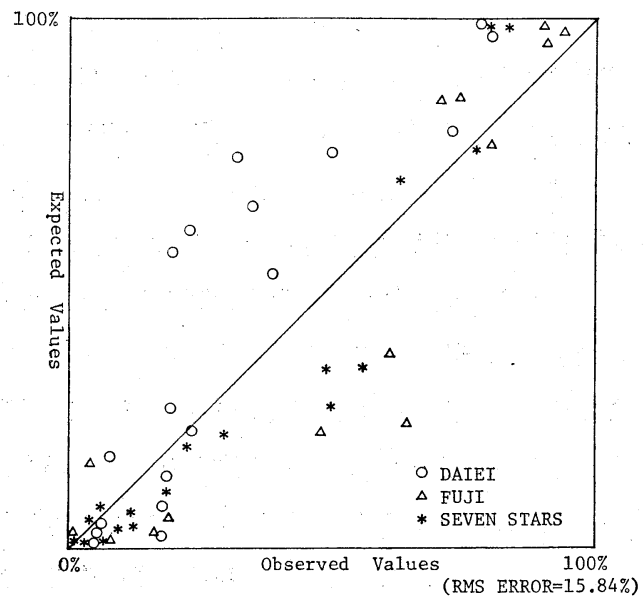

第 4 図ハフモデルの予測值と実測值

值を示すパラメータ $\alpha$ の値は 0.10 10あった．店舗規 模にパラメータをつけただけで適合度が $6 \%$ 以上も 上昇しているが，八フ型モデルがハフモデルに比較 して，常にこれほど適合度が上昇するわけではない。 第 1 表から明らかなように，ダイエーの店舗規模は $4,000 \mathrm{~m}^{2}$ と他の 2 店に比し，約 3 倍もある. した がって, 店舗規模にパラメー夕を用いない八フモデ 儿の場合，店舗規模の差異が予測結果に大きな影響
第 4 表N.・型モデルによる予測選択確率

\begin{tabular}{|c|c|c|c|}
\hline メッシュ番号 & ダイエー & フ $シ$ & セブンスター \\
\hline 1 & $52.1 \%$ & $11.2 \%$ & $36.7 \%$ \\
\hline 2 & 81.2 & 5.6 & 13. 2 \\
\hline 3 & 45.7 & 40.7 & 13. 6 \\
\hline 4 & 97.4 & 0.6 & 2.0 \\
\hline 5 & 50.7 & 3. 6 & 45.7 \\
\hline 6 & 12.3 & 79.2 & 8.5 \\
\hline 7 & 33.2 & 47. 6 & 19.3 \\
\hline 8 & 41.8 & 8.8 & 49.4 \\
\hline 9 & 1.1 & 0.3 & 98.7 \\
\hline 10 & 18. 7 & 5.1 & 76.2 \\
\hline 11 & 5.9 & 88.9 & 5.2 \\
\hline · $\quad 12$ & 0.3 & 99.4 & 0.3 \\
\hline 13 & 14. 2 & 72.2 & 13.5 \\
\hline 14 & 34.9 & 33.6 & 31.4 \\
\hline 15 & 30.8 & 26.4 & 42.8 \\
\hline 16 & 20.0 & 12.8 & 67.2 \\
\hline 17 & 3.6 & 93.6 & 2.7 \\
\hline 18 & $\cdot 8.9$ & 77.6 & 13.5 \\
\hline
\end{tabular}

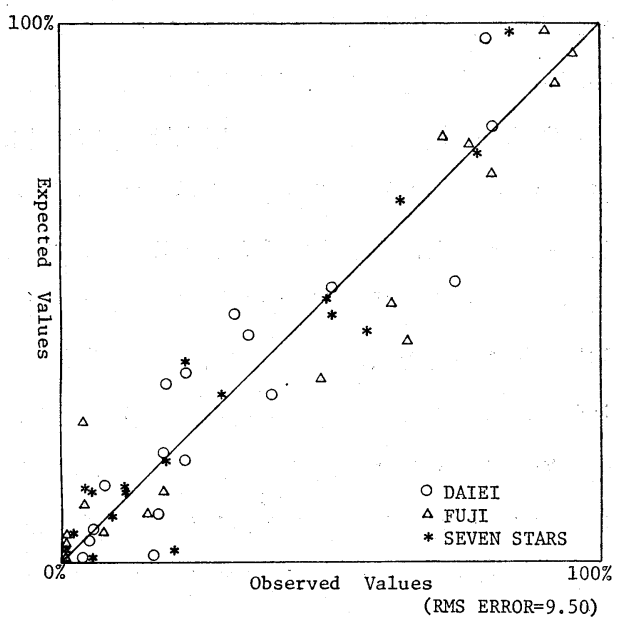

第 5 図 ハフ型モデルの予測值と実測值

を与えるのに対し，店舗規模にパラメー夕を用いる ハフ型モデルの場合，店舗規模の差異が緩和される 結果となり，これが両モデルの適合度に重大な差異 をもたらしたものと考えられる. このことは第 4 図 と第 5 図を比較すればより明確となる.すなわち， ハフモデルの場合，ダイエーに対する予測は実測值 に対し予測值が非常に過大に評価されているが，八 フ型モデルの場合には，この傾向はほとんど見られ 
第 5 表 提案モデルによる予測選択確率

\begin{tabular}{c|c|c|c}
\hline メッシュ番号 & ダイエー & \multicolumn{1}{|c|}{ フ } & セブンスター \\
\hline 1 & $67.4 \%$ & $13.6 \%$ & $19.0 \%$ \\
2 & 75.8 & 8.1 & 16.1 \\
3 & 60.6 & 29.9 & 9.5 \\
4 & 84.9 & 4.5 & 10.6 \\
5 & 64.9 & 5.9 & 29.2 \\
6 & 16.1 & 75.7 & 8.1 \\
7 & 20.7 & 69.9 & 9.4 \\
8 & 28.0 & 5.9 & 66.1 \\
9 & 10.6 & 4.5 & 85.0 \\
10 & 16.9 & 8.2 & 74.9 \\
11 & 12.8 & 77.2 & 10.0 \\
12 & 8.3 & 85.7 & 6.0 \\
13 & 11.9 & 75.9 & 12.2 \\
14 & 42.7 & 40.7 & 16.6 \\
15 & 24.4 & 22.4 & 53.2 \\
16 & 16.2 & 11.7 & 72.1 \\
17 & 11.7 & 79.3 & 9.1 \\
18 & 11.9 & 72.5 & 15.7 \\
\hline
\end{tabular}

ない.これ以外の点については, 両モデル間に体系 的な差異は認められないので，店舗規模の大なるダ イエーに対する過大評価の有無が両モデルの適合度 に大幅な差異を生じさせたものと考えられる.した がって，比較的接近し，かつ規模のかなり異なる店 舗間に対してハフモデルを適用すると，規模の大な る店舗に対する過大評価が生じる傾向があると指摘 できよう。

2）提案モデルによる予測結果

第 5 表に, $\mu_{j}$ として店舗の売場面積, $d_{i j}$ として 店舗と消費者間の直線距離を用いた，提案モデルに よる各メッシュの各スーパーに対する予測された選 択確率を示す．また，現実の選択確率と予測された 選択確率の関係を図示したのが第 6 図である. 最大 の適合度の場合の $\lambda$ の值は 22.1 であり, $\beta$ の值は 0.97 であり，適合度を表わす $\mathrm{RMS}$ 誤差は $10.5 \%$ で あった. 適合度という点では, ハフ型モデルと約 1 \%の差異で大差なく，一方ハフモデルとは約 $5 \%$ の 差異がある. この結果から, 今回提案したモデルは, 八フモデル, ハフ型モデルと同様, 店舗規模と距離 という二つの要因のみを使用したが，予測精度とい

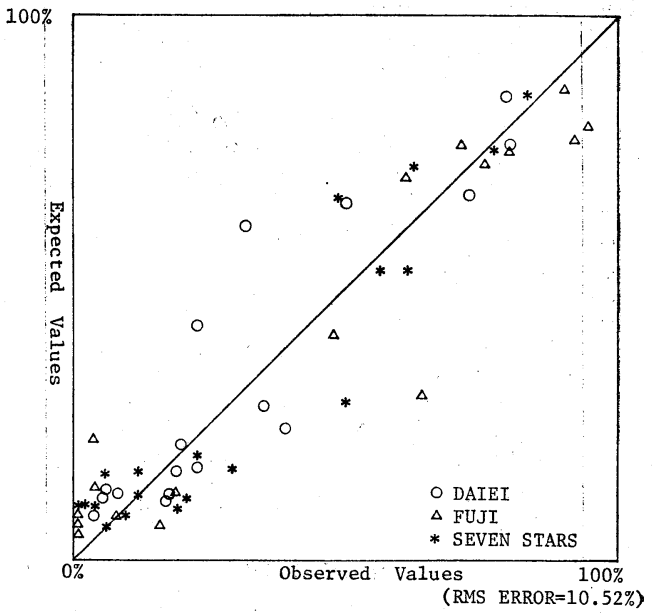

第 6 図提案モデルの予測值と実測值

う点ではハフ型モデルとほぼ同等であり，ハフモデ ルよりはかなり高い精度をもったモデルであると指 摘できよう．予測值という視点から見た提案モデル の特徴としては，ハフ型モデルと比較してダイエー に対して 2,3 のゾーンで過大評価が見られること， ハフ型モデルでは予測值が $0 \%$ ないしそれに近い值 を示すむのがいくつか見られるのに対し，提案モデ ルではこの傾向が見られないことなどが指摘できよ 亏.

このような特徽をより明確に考察しようとして作 成したのが第 7 図と第 8 図であり，横軸は提案モデ ルの予測值を，縦軸はハフモデル，ハフ型モデルの 予測值を示している. ハフモデルとの比較では, 全 体的に見て両モデル間にそれ程の類似性が見られな い. 特に店舗規模の大なるダイエーに対して, この 傾向は顕著である. 一方，八フ型モデルとの比較で は, 両モデル間にかなりの類似性が認められる。し たがって，今回提案したモデルは，予測の適合度と いう点に関しても，また予測值の分布に関しても， ほぼハフ型モデルと同等の機能を有していると考え られる。 


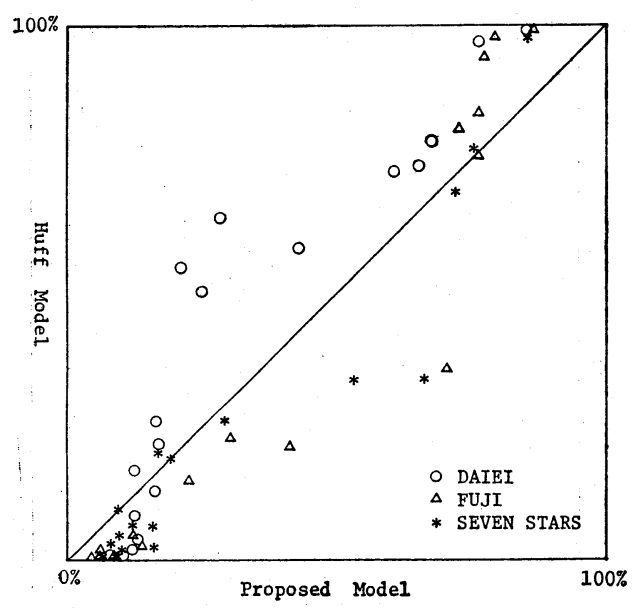

第 7 図提案モデルとハフモデルの予測值 の分布

\section{$\mathbf{V}$ 結 論}

本研究は，ハフモデルに代表される従来の確率的 商圈設定モデルの有用性を認めつつも，それらのモ デルが Luce の提唱した個人選択公理をその理論的 根拠としているため, 消費者の店舗選択メカニズム という視点から見た時, 必ずしも満足のいく理論モ デルでないという問題点を指摘し，新たに消費者の 店舗選択メカニズムを明確に定義した確率モデルを 提案した. さらに, 提案モデルの有用性, ならびに 従来のモデルとの予測結果を比較考察すべく，松山 市石井地区で実施した購買行動の調査結果を用いて 解析を実施した. その結果以下の諸点が明らかとな った.

1. 消費者の店舗に対する評価值が全体としてあ る種の正規分布に従い，この条件下で消費者がある 特定の店舗を選択する確率は，その店舗に対する評 価值が他の店舗に対するそれよりも高い確率である という店舗選択メカニズムを考えることにより，従 来のモデルとは異なり，かつ選択メカニズムが明確 に定義された確率的商圈設定モデルを構築すること が可能となった.

2. この提案モデルは, 従来のモデルと同様, 確

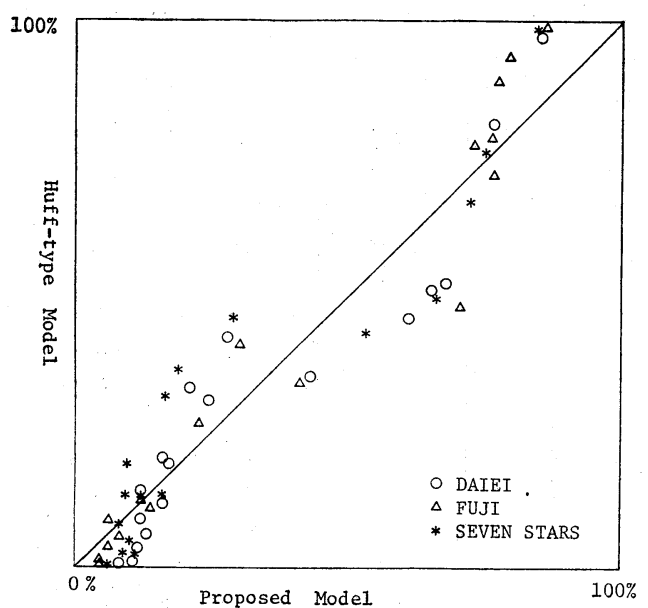

第 8 図提案モデルとハフ型モデルの予測值 の分布

率的モデルとしての必要条件, $0 \leq P_{i j} \leq 1, \sum_{j=1}^{n} P_{i j}=$ 1，を満足するものである.

3. ハフ型モデルの RMS 誤差は $9.50 \%$ あ゙あるの に対し，ハフモデルのそれは $15.86 \%$ であり，前者 の適合度が約 $6 \%$ も高い：この差異は，両モデルを 規模がかなり異なり，かつかなり接近した店舗群に 対して適用したために生じたものと考えられる.し たがって，このような条件下でハフモデルを適用す ると，規模の大なる店舗が過大に評価され，予測值 が実測値よりかなり高く推定される結果が導かれる 危険性がある.

4. 提案モデルの RMS 誤差は $10.5 \%$ であり，適 合度という点では八フ型モデルと大差なく，また予 測值の分布という点についても両モデルは類似した 傾向を示す.

5. したがって，提案モデルは適合度という点で 従来のハフ型モデルと比肩しうるし，かつ消費者の 店舗選択メカニズムがより明確なモデルであると結 論できる.

以上が本論文の主要な結論であるが，今後に残さ れた課題としては, 生鮮食品以外の財について本モ デルの有用性を検討すること，消費者の属性による 購買行動の差異を明確にすること，分布の特定化， 
すなわち未知パラメータの推定をより一層簡単にで

きる方法を見い出すこと，などが考えられる.

本論文を作成するにあたり，論文全体にわたっては愛 媛大学横山昭市教授に，モデルの基本的考え方について は徳島大学青山吉隆助教授に, そして数值計算に関して は愛媛大学山本哲朗教授に貴重な御示唆をいただいた。 また資料の収集については，松山商工会議所，ダイエー, フジ，セブンスター各店にそして資料の收集・整理に はセイコー社の古川未知子氏に御協力をいただいた．未 筆ながら深く感謝の意を表します。

本論文は, 1980年春季学術大会において発表したもの に修正・加筆したものである.なお，本研究の実施にあ たっては, 昭和54年度文部省科学研究費奖励研究(A), 課 題番号479169の一部を使用した.

$\left(\begin{array}{ll}\text { 投稿 } & 1980 \text { 年 } 7 \text { 月 } 25 \text { 日 } \\ \text { 受理 } & 1980 \text { 年 } 11 \text { 月 } 1 \text { 日 }\end{array}\right)$

\section{注}

1) 本報告書は田村正紀 (神戸大) ・阿部周 造(横浜 国大)の両氏が中心となって作成されたものであ る.

2) ハフ型モデルと M.C.I. モデルとの明確な区別 はない.ここでは，式(3)で示される店舗規模と 距離の二つの説明要因を用いるモデルをハフ型モ デル，三つ以上の説明要因を用いるモデルを $\mathbf{M}$.

C. I. モデルとした.

3 ) Nakanishi and Cooper (1974) が提案したパラ メー夕推定の方法は，変数の対数をとり線型回帰 式へ変換することが必要であるので，ゼロ值をと る変数を含めることができない．このゼロ值をと る変数の処理の仕方として，人為的に非常に小さ な値を与えるやり方が提案されているが(産業研 究所, 1979)，筆者の経験では，非常に小さな值と して具体的にどのような数值を与えるかによって 結果が非常に異なってくる. それは，Nakanish and Cooper が提案したパラメータ推定法に打い て，ゼロ值をとる変数がある場合， $0 / 0$ という不 定型を解くことになるからである．したがって， ゼロ值をとる変数がある場合には，これをデータ から取除いてパラメー夕を推定するか，または産 業研究所 (1979)が提案した理論值を推定し，これ をゼロ值の代りに使用する必要がある.

4）このモデルの基本的考え方については，1980年 度春季学術大会において発表した(藤目，1980)。

5 ) 複合シンプソン公式とは, ある関数 $f(x)$ を積 分区間 $a$ から $b$ まで積分した值が近似的に次式で 求まるというものである.

$$
\begin{gathered}
\int_{a}^{b} f(x) d x \fallingdotseq \frac{h}{3}\left(f_{0}+4 f_{1}+2 f_{2}+4 f_{3}+\right. \\
\left.\cdots \cdots+4 f_{n-1}+f_{n}\right)
\end{gathered}
$$

ここで $n$ を任意の偶数とすると, $h=(b-a) / n$ で あり, $f_{0}=f(x=a), f_{i}=f(x=a+h i), f_{n}=f(x$ =b) である. 本研究では， $\mathrm{a}, \mathrm{b}$ としてそれぞれ $-6,+6$ ( 6 標準偏差)を用いて積分を行なった.

$6 ） \sigma_{j}$ と $\mu_{j}$ の間にこのような関係を仮定したのは, 店舗に対する評価值の平均值 $\left(\mu_{j}\right)$ が大きくなれば なるほど，消費者の店舗に対する評価のバラツキ $\left(\sigma_{j}^{2}\right)$ も大きくなると考えたからである.

7) 3 スーパーの存在を認知している標本のみをデ 一タとして用いたのは，消費者が存在するすべて の店舗を認知し，かつそれに対して評価を行なっ た上で特定の店舗を選択するというモデルの基本 的前提があるからである。

8 ) RMS 誤差とは，残差平方和の平均值の平方根 (Root Mean Square) を表わし，この值が小さい 程適合度が高い，適合度として相関係数がよく用 いられているが，相関係数は 2 変数間の直線関係 の程度を表わすのであって，決して適合度を表わ すものではない，そこで，本研究では適合度を表 わす指標として RMS 誤差を用いた。

\section{文 献}

産業研究所編 (1979)：『大型小売店の出店によるそ の周辺の中小小売店への影響メカニズムに関する 研究』, 116ページ。

中西正雄 (1979): 小売引力法則の再検討 (上). 季刊 消費と流通. 3-1，93 98.

藤目節夫 (1980)：消費者行動の確率的モデル，地理 予，18，252 253.

山中均之 (1971)：小壳商圈研究一大都市対衛星都 市——. 甲南経営研究, 12-3，37 63.

山中均之 (1974)：ショッピング・センターの規模に

関する研究. 甲南経営研究，15-2，25 49.

山中均之 (1979): 衛星都市小売商圈の分析. 甲南経 営研究, 20-2, 1 17.

山本哲朗 (1976):『数值解析入門』サイエンス社, 181 ページ.

Bucklin, L. P. (1971): Retail gravity models and consumer choice: A theoretical and empirical critique. Economic Geography, 47, 489 497.

Converse, P. D. (1949): New laws of retail gravitation. Journal of Marketing, 14, 379 384.

Gambini, R., Huff, D. L. and Jenks, G. F. (1967): Geometric properties of market areas. Regional Science Association : Papers, 20, Hague congress, 
$85 \sim 92$.

Godlund, S. (1956): The function and growth of bus traffic within the sphere of urban influence. Lund Studies in Geography, series B. Human Geography Nr. 18. 20 39.

Huff, D. L. (1964): Defining and estimating a trading area. Journal of Marketing, 28, 34 38.

Huff, D. L. and Lutz, J. M. (1979): Ireland's urban system. Economic Geography, 55, 196 212. Kotler, P. (1971): Markeling decision making. A model building approach. New York: Hort, Rinehart \& Winston, 127 141 .

Nakanishi, M. and Cooper, L. G. (1974): Parameter estimation for a multiplicative competitive interaction model-least squares approach. Journal of Marketing Research, 11, 303 311.

Reilly, W.J. (1931) · The law of retait gravitalion. New York.

Stanley, T. J. and Sewall, M. A. (1976): Image input to a probabilistic model: predicting retail potential. Journal of Marketing, 40, 48 53.

Thompson, D. J. (1966) : Future directions in retail area research. Economic Geography, 42, 1 18.

Tuominen, O. (1949) Das Einflußgebiet der Stadt Turk in System der Einflußgebiete SW-Finnland. Fennia, 71, 114 134.

\section{THE STRUCTURE OF PROBABILISTIC TRADE AREA DELIMITATION MODELS}

\section{Setsuo FUJIME*}

Since D. L. Huff proposed a probabilistic trade area delimitation model for the delimitation of a trade area (the Huff model), a number of attempts applying the extentions of the Huff model have been devised to analyze competitive market behavior. These models are generally called the Huff-type model or the multiplicative competitive interaction (M. C. I.) model. The theoretical basis of these models relies to a large extent on the Luce choice axiom. It assumes the one-to-one correspondence between choice ratio which is the probability of a consumer in an area shopping at a certain store and relative utility which is the utility ratio of a certain store to an aggregate utility of all stores which the consumer can patronage. However, there is no proof of the existence of one-to-one correspondence. Therefore, the Huff and Hufftype models which rely on the Luce choice axiom do not have the evident store choice mechanism.

The purpose of this study is to build an alternative probabilistic model which is strictly defined in terms of consumer behavior, and to compare this model with the Huff and Huff-type models.

Main charateristics of this new model are as follows:

Let $X_{i}$ be consumers' utility on the $i$ th store in a given district. As the utility $X_{i}$ is not the same to all consumers in the district, we assume that randam variable $X_{i}$ is normally distributed with mean $\mu_{i}$ and variance $\sigma_{i}{ }^{2}$. Furthermore, we assume that the probability choosing a certain store is equal to the probability that a certain siore's utility is greater than the other stores' utility.

In case of three stores (denoted $1,2,3)$, the probability that store 1 would be chosen $\left(P_{1}\right)$ may be stated as follows: 


$$
\begin{aligned}
P_{1} & =P_{r}\left[x_{1}>x_{2}, x_{1}>x_{3}\right] \\
& =\int_{-\infty}^{\infty} f_{1}\left(x_{1}\right) \int_{-\infty}^{x_{1}} f_{2}\left(x_{2}\right) \int_{-\infty}^{x_{1}} f_{3}\left(x_{3}\right) d x_{3} d x_{2} d x_{1} \\
& =\int_{-\infty}^{\infty} \frac{1}{\sqrt{2 \pi}} e^{-z_{1} / 2} \int_{-\infty}^{k_{2}} \frac{1}{\sqrt{2 \pi}} e^{-z_{2} 2 / 2} \int_{-\infty}^{k_{3}} \frac{1}{\sqrt{2 \pi}} e^{-z_{3} / 2} d z_{3} d z_{2} d z_{1}
\end{aligned}
$$

where $f_{i}\left(x_{i}\right)$ is the probability density function of $X_{i}$, the function $Z_{i}=\left(X_{i}-\mu_{i}\right) / \sigma_{i}$ is normally distributed with mean zero and variance one, and $K_{j}=\left(X_{1}-\mu_{j}\right) / \sigma_{j}$.

The following results were obtained applying this model to the data about Matsuyama City.

1) Assuming that the consumers evaluations of store attraction is normally distributed and that the choice ratio in which consumers choose a certain store is equal to the probability that the evaluation of the store is greater than those of the other stores, the author was able to build an alternative probabilistic model which has more clear choice mechanism than the usual ones.

2) The proposed model, as the probabilistic model satisfies the necessary conditions, $0 \leqq P_{i j} \leqq 1, \sum_{j=1}^{n} P_{i j}=1$.

3) The R. M. S. error obtained from the Huff-type model is $9.5 \%$ and that obtained from the Huff model is $15.86 \%$. In terms of fitness the former is about $6 \%$ better than the latter. This difference is considered to be caused by applying both models to close-by stores which have different selling space. Accordingly, if the Huff model is applied to this situation, it is expected that stores having greater selling space have larger expected values than observed ones.

4) As the R. M. S. error obtained from the proposed model is $10.5 \%$, there is no significant difference in terms of the goodness of fit between the proposed model and the Huff-type model. Furthermore, both models have similar distributions of predicted values.

5) Therefore, the proposed model has the same performance as the Huff-type model, and at the same time it has more clear store choice mechanism than the usual probabilistic models. 